\title{
Intraspecific variation in preserved specimens of the fiddler crabs Uca panacea and Uca pugilator (Decapoda: Ocypodidae)
}

\author{
Luis E. A. Bezerra ${ }^{1,2} \&$ Petrônio A. Coelho ${ }^{1}$ \\ 1 Programa de Pós-Graduação em Oceanografia, Departamento de Oceanografia, Universidade Federal de Pernambuco. \\ Avenida da Arquitetura, 50740-550 Recife, Pernambuco, Brasil. \\ ${ }_{2}^{2}$ Corresponding author. E-mail: luiseab@gmail.com
}

\begin{abstract}
The fiddler crabs Uca panacea Novak \& Salmon, 1974 and Uca pugilator (Bosc, 1802) are closely related North American species that are sympatric along the north coast of Gulf of Mexico. Since U. panacea was described, there has been confusion in the identification these two species. Morphological differences between these two fiddlers have been pointed out in recent years, mainly regarding the presence of a pigment spot and granulations on the dorsal margin of carapace in $U$. pugilator. We report herein some intraspecific differences between the two species that we believe to be useful in avoiding misidentification among preserved specimens of these two fiddler crabs, such as the absence of the pigment spot in $U$. pugilator and the presence of the pigment spot and granulations on dorsal margin of carapace in U. panacea as well. Our results have also revealed that $65 \%$ of the $U$. pugilator specimens examined possess a gape pile in the major chela, which is not a reliable diagnostic character, but could be useful when present. The gonopods of both species were analyzed using SEM, confirming the previous statement that the sub-terminal thumb is shorter in U. panacea than in U. pugilator. Finally, as important morphological characters are missing in the original description of $U$. panacea, a redescription of this species is also provided.
\end{abstract}

KEY WORD. Distinctness; Gulf of Mexico; morphological characteristics; SEM analysis.

The fiddler crabs Uca panacea Novak \& Salmon, 1974 and Uca pugilator (Bosc, 1802) are closely related species with the former occurring along the Gulf of Mexico coast, from north of Tampa Bay, Florida to Veracruz, Mexico, whereas the latter occurs along the eastern coast of United Sates and Gulf of Mexico, from Massachussetts to Texas, Bahamas, and Santo Domingo (Dominican Republic) (Crane 1975, Barnwell \& Thurman 1984). A previous study by RAo \& Fingerman (1968) described two variants of $U$. pugilator based on coloration pattern from the Panacea area, Florida, United States. Later studies by FeLDER et al. (1971) and Selander et al. (1971) revealed differences in electrophoretic properties that showed that Gulf coast specimens thought to be $U$. pugilator could be placed in two distinct groups. These results were the clues to NovaK \& SALMON (1974) that the southern population in the Gulf of Mexico, believed to be $U$. pugilator, represented a distinct species.

Following the description of $U$. panacea, studies by SALMON et al. (1978), Salmon \& Hyat (1979), and Pawlik et al. (1980) showed acoustic and waving display specificity between the two species, as well as reproductive isolation in their area of sympatry. Moreover, the distinct differences in the form of the spoon-tipped setae on the second maxilliped are an indication of niche specialization (NovaK \& SALMON 1974). Thus, distinction between these two species is apparently easy in the field, based on differences in waving display, color, and niche spe- cialization. On the other hand, the two species are very similar in morphology and a confident distinction between preserved specimens of these two fiddlers is a challenge for carcinologists, especially in the case of females.

NovaK \& SALMON (1974) in describing U. panacea attempted to separate the species based on carapace size, length and size of major cheliped, gonopod morphology, and carapace pigmentation. However, characteristics such as size and carapace pigmentation are not consistent enough to make them reliable diagnostic characters and were judged to be so variable as to be inadequate for the establishment of new species (Crane 1975, BarnwELL \& Thurman 1984). Regarding the gonopods, von Hagen (1980) pointed out that, in contrast to the drawings given by the species authorities, the gonopods of the holotype of $U$. panacea were found to be identical with those of $U$. pugilator, and there are no other morphological characters that could serve for clearly separating the holotype of $U$. panacea from $U$. pugilator.

BARNwell \& THURMAN (1984), while studying the taxonomy and biogeography of $U c a$ Leach, 1814 species in the Gulf of Mexico, attempted to clarify some points regarding the $U$. panacea description and revealed some differences between the two species based on the examination of series of specimens. They noted the presence of small granulations and a purple pigmentation spot on dorsal margin of carapace in $U$. pugilator, a more arched branchial region in $U$. panacea, and the anterior surface 
of the first ambulatory more numerously granulated in $U$. panacea than in $U$. pugilator. Moreover, the authors also noted a slight difference between the gonopods.

However, the analysis of preserved species has revealed some intraspecific differences regarding those characteristics. Due to the difficulties in the reliable identification of these two species, the aim of this study is to provide information about intraspecific variability that we believe to be useful in avoiding misidentification among preserved specimens of these two fiddler crabs. A scanning electron microscopy (SEM) analysis of gonopods is presented in order to try to clarify the differences in gonopod morphology. Moreover, as some morphological features, especially in females, are missing from the original description of $U$. panacea, and standard taxonomic rules were ignored, a redescription of this species is provided.

\section{MATERIAL AND METHODS}

The fiddler crabs examined in this study are deposited in the National Museum of Natural History, Smithsonian Institution, Washington DC, USA (USNM) and in the American Museum of Natural History, New York City, USA (AMNH). Holotype and paratypes of $U$. panacea as well as additional material were examined and compared with $U$. pugilator specimens present in those collections. The gonopods of $U$. pugilator and U. panacea were examined using scanning electron microscopy. Gonopods used for SEM analysis were taken from a paratype of $U$. panacea (USNM 150089), and from specimens of both species collected inside and outside of the area of sympatry (U. panacea: USNM 171530; USNM 180188. U. pugilator: USNM 6440; USNM 55553; USNM 17186). The gonopods were prepared according to the methodology proposed by Felgenhauer (1987).

Abbreviations used in this study: (SEM) Scanning Electron Microscopy; (Co.) County; (m) male; (f ) female; (ovf) ovigerous females.

\section{TAXONOMY}

\section{Uca panacea Novak \& Salmon, 1974}

Figs 1-4, 8, 11-13

Gelasimus pugilator Stimpson, 1859: 62 in part; Smith, 1870: 136 in part.

Uca pugilator Ortmann, 1897: 352 in part; Rathbun, 1900: 585 in part; 1918: 400 in part; Fingerman, 1956: 274, 1957: 7; Rao \& Fingerman, 1968: 27; Crane, 1975: 223 in part).

Uca panacea Novak \& Salmon, 1974: 313, figs 1-7; Powers, 1977: 53; Salmon et al., 1978: 252; Barnwell \& Thurman, 1984: 41).

Type locality: Panacea, Florida, United States.

Material examined: 127 males; 73 females. Holotype (USNM 150096, 1m); allotype (USNM 150097, 1f); paratype (USNM 150098, 50m, 50f). United States, Florida: Alligator Harbor (USNM 90748, 4m, 1f); Alligator Harbor (USNM 90749, 1m); Panacea (USNM 125578 part, 3m); Carabelle (USNM 244066, 33m); Pensacola (USNM 244075, 3m); Alabama, Mobile County: Bayou la Batre, Point Aux Pins (AMNH 9030, 22m, 11f as Uca sp.); Dauphin Island (AMNH 9097, 3m, 3f as Uca sp.); Texas: Corpus Christi (USNM 138637, 1m, 1f); Ingleside (USNM 72189, 3m, 3f); Mexico: Tamaulipas, Laguna San Andres (USNM 171530, 1m, 1f); Campeche, Laguna de Terminos (USNM 180189, 1m, 1f); Veracruz, Laguna La Mancha (USNM 180188, 1m, 1f).

Male redescription. Carapace: carapace moderately arched; front wide, contained about three times in width of carapace between antero-lateral angles. Antero-lateral margins slightly divergent, angling bluntly into dorso-lateral margin, which is slightly beaded. Postero-lateral stria short, faint, located immediately above $4^{\text {th }}$ ambulatories. H-form cardiac depression moderately outlined, colored rust-red. Dorsal margin of carapace without pile, but with fine granulations along antero- and dorso-lateral margins. Pair of small brown spots slightly anterior to $\mathrm{H}$-form depression, two additional purple pigmentation spots near the base of front and two white spots externally to purple pigmentation, near upper margin of eyebrow. Orbits moderately oblique; eyebrow almost vertical, but well visible in dorsal view, breadth about half of diameter of adjacent part of depressed eyestalk, lower margin beaded. Suborbital margins with crenellations little developed internally, becoming more developed and separated along outer orbital margin, not obscured by setae or pile. Row of setae on floor of orbit, immediately above sub-orbital crenellations. All abdominal segments distinct, not fused. Pleonal clasping or lock apparatus present. Minor cheliped: merus slender, dorsal margin convex; antero- and postero-ventral margins straight. Carpus without tubercles or tuberculate ridge. Pollex and dactyl longer than palm; gap narrow, inner margins with few serration, long in proximal end, decreasing distally, not in contact; tip of dactyl and pollex with row of soft long hairs on ventral margins. Major cheliped: antero-dorsal margin of merus straight, arching near distal end; ventral margin straight, with blunt tubercles increasing in size distally. Antero-dorsal margin of carpus with row of tubercles, ending in strong, blunt proximal tubercle; inner margin with oblique tuberculate ridge formed by indistinct tubercles, almost absent near upper end. Outer manus covered by large tubercles, decreasing in size near ventral margin; longitudinal keel starting in distal third, at about middle manus, well above ventral margin, and extending along most of pollex on ventral half, poorly developed distally. Palm covered by larger tubercles, merging in small tubercles in lower region. Oblique tuberculate ridge absent, no tubercles along margin of carpal cavity. Upper margin of carpal cavity with pile in proximal end. Oblique pre-dactyl tuberculate ridge formed by larger tubercles, continuing downward along inner margin of pollex. Dactyl long and curved downward. Pollex straight, slightly turned upward, with serration along inner and outer margin. Row of tubercles in center of pollex, with enlarged teeth halfway to its tip, and other near the tip of pollex. Both pollex and dactyl slender and flatted. Gape pile absent. 

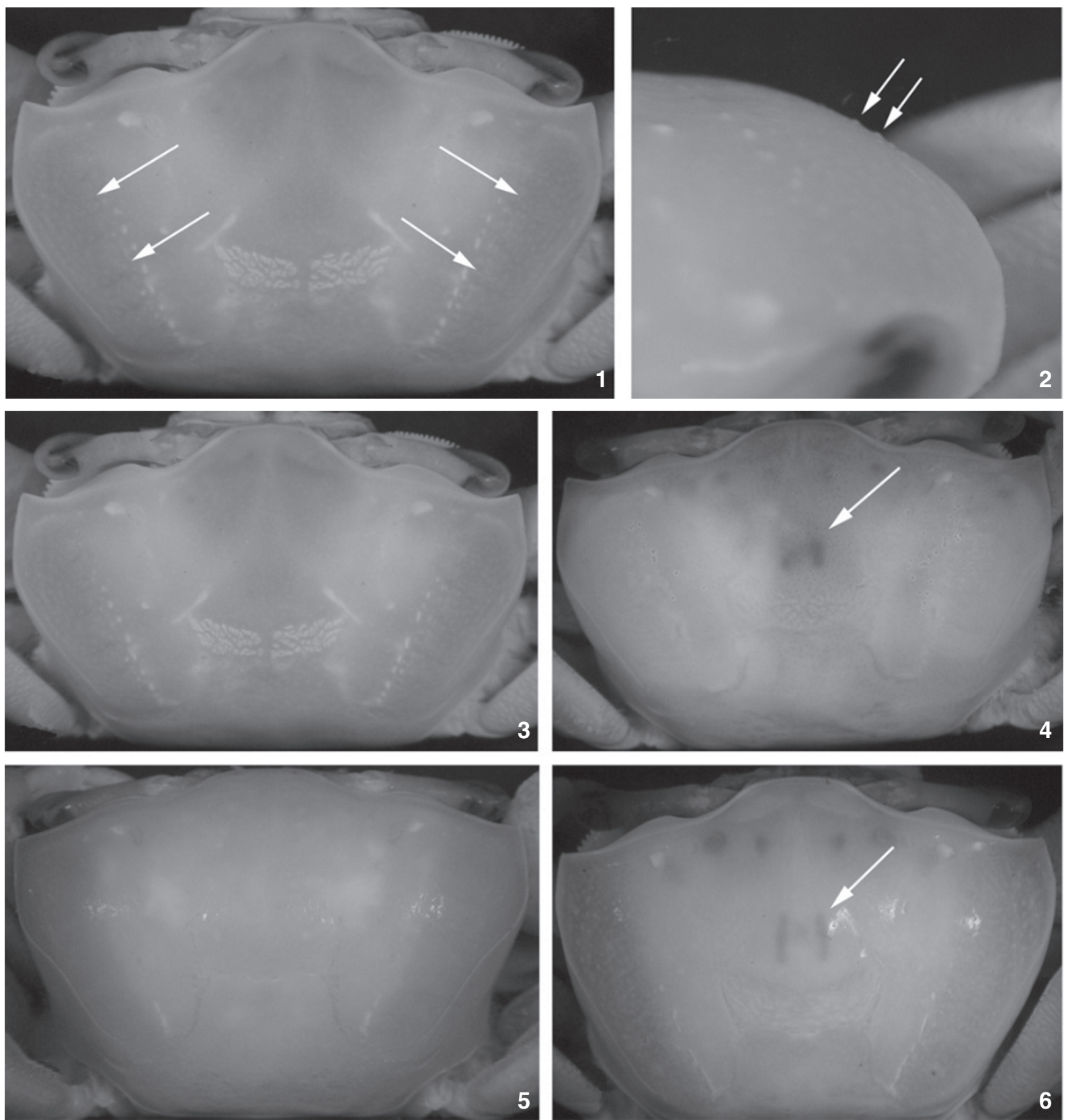

Figures 1-6. (1-2) Small tubercles on dorsal margin of carapace in Uca panacea (arrows). (1) Dorsal view; (2) frontal view. (USNM 171530), left-handed male, carapace width $17 \mathrm{~mm}$, Mexico, Tamaulipas; (3-6) Dorsal margin of carapace of U. panacea (3 and 4 ) and U. pugilator (5 and 6) showing the presence (arrows) and absence of the gnathobases attachments on both species. (3) U. panacea (USNM 171530), left-handed male, carapace width 17 mm, Mexico, Tamaulipas; (4) U. panacea (USNM 180188), right-handed male, carapace width $18 \mathrm{~mm}$, Mexico, Laguna La Mancha; (5) U. pugilator (USNM 55553), right-handed male, carapace width 16 mm, United States, Virginia; (6) U. pugilator (USNM 6440), right-handed male, carapace width 23 mm, United States, Pine Key, Florida.

Ambulatories: merus slender, dorsal margin almost straight with row of setae on major side, and armed with short oblique rows of small tubercles on minor side; antero- and postero-ven- tral margins slightly convex, and beaded on minor side. Carpus and manus without serrations or rugosities. First ambulatory on major side with merus, carpus and manus roughened anteriorly 

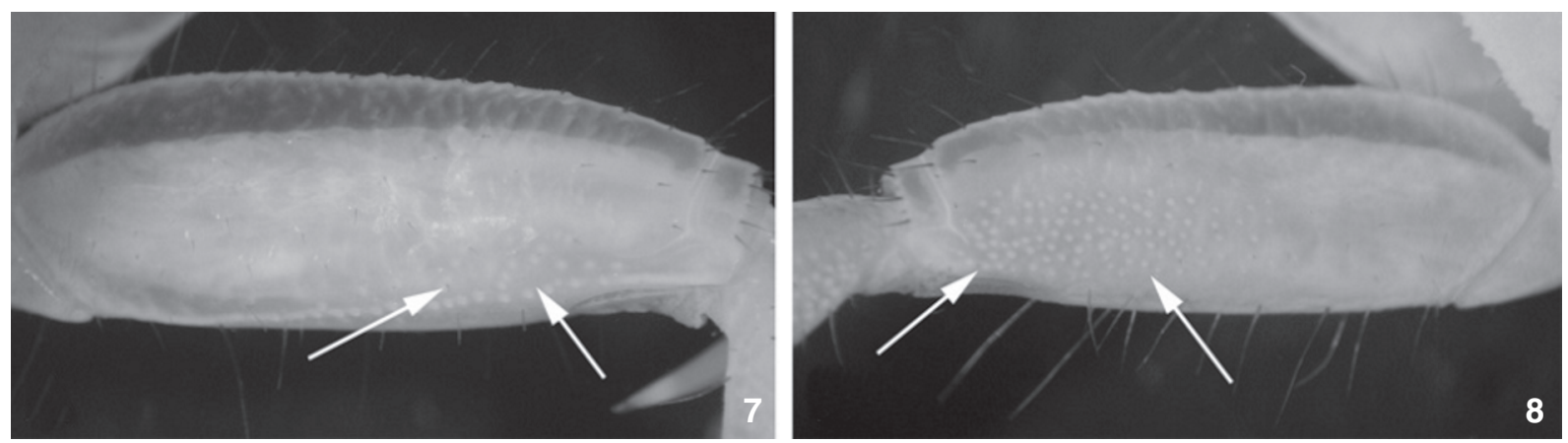

Figures 7-8. Anterior surface of first ambulatory on major side of U. pugilator and U. panacea. (7) U. pugilator (USNM 125578 part), carapace width $16.7 \mathrm{~mm}$, United States, Panacea, Florida. (8) U. panacea (USNM 125578 part) carapace width 15.7mm, United States, Panacea, Florida.

with tubercles on lower anterior surface. No pile on ambulatories. Gonopod: sub-terminal thumb slender, short, about one third of distal length of gonopod from tip to base of sub-terminal thumb.

Female redescription. Carapace: dorsal surface finely granulated, mainly near antero- and postero-lateral margins, which are both beaded. Postero-lateral stria long, beaded, located immediately above $4^{\text {th }}$ ambulatories. Suborbital crenellation stronger than in males, with two rows of setae on floor of orbit, immediately above sub-orbital crenellations. Abdominal segments not fused.

Minor cheliped: as in males.

Ambulatories: merus slender as in males, without row of setae on dorsal margin, which are numerous and long in ventral margins. Setae in dorsal margin are sparse and short. Short oblique rows of tubercles in dorsal margin of merus stronger than in males, in both sides, as well as the serrations in antero- and postero-ventral margins. Carpus and manus rugose throughout; antero-dorsal margins of $3^{\text {rd }}$ and $4^{\text {th }}$ legs armed with serrations.

Gonopore: roughly triangular, not tuberculate.

Remarks: this description was based on the holotype deposited at the USNM. The following remarks are based on the examination of paratypes and additional material. The color pattern in carapace of preserved specimens is very variable, being completely absent in some of them. The postero-lateral stria in some males is not as faint as in the holotype. One of the following characters can be absent in major cheliped in some specimens: the blunt tubercle in the antero-dorsal margin of carpus, the enlarged teeth in the inner margin of pollex, and the pile in the upper margin of carpal cavity.

\section{Uca pugilator (Bosc, 1802)}

Figs 5-7, 9, 10, 14-16

Ocypoda pugilator Bosc, 1802: 197.

Gelasimus pugilator Le Conte, 1855: 403; Stimpson, 1859: 62 in part; Smith, 1870: 137 in part; Kingsley, 1880: 150 in part; Ives, 1891: 192.
Uca pugilator Ortmann, 1897: 352 in part; Rathbun, 1900: 585; 1918: 400 in part; Salmon \& Stout, 1962: 15; Crane, 1975: 223; Salmon et al., 1978: 252; Barnwell \& Thurman, 1984: 40. Gelsimus pugilator: Hyman, 1920: 485.

Type locality: "Caroline", United States. Type not extant.

Material examined: 734 males; 253 females; 14 ovigerous females. United States, Massachusetts: (USNM 32481, 2m, 1f); Cape Cod (USNM 143599, 1m); Barnstable Co., Cape Cod, First Encounter Beach (AMNH 14756, 31m, 2f); (AMNH 14737, 46m, 8ovf); Wellfleet, Light Island (AMNH 14701, 39m); New York: Long Island (USNM 43356, 1m); Easthampton, (AMNH 2405, 7m, 2f); Nassau Co., Oyster Bay (USNM 138635, 15m, 7f); Brooklin Kings Co., near Coney Island, Plum Beach (AMNH 14754, 3m, 5f); New York harbor (AMNH 55, 2m); Cartest Co., Beaufort, W of Davis Fish Co. (AMNH 14763, 3m, 33f); Virginia: Smith's Island (USNM 74453, 20m, 14f, 2ovf); Lynnhaven Bay (USNM 55553, 13m, 10f, 1ovf); North Carolina: Beaufort (USNM 71316, 2m, 1f); Morehead City (USNM 22184, 3m, 3f); Carteret Co. (AMNH 14734, 26m); (AMNH 14748, 44m); (AMNH 14772, 16m); South Carolina: (USNM 17186, 23m, 8f); (USNM 17187, 4m, 2f); (USNM 17188, 5m, 5f); Kendal (USNM 22280, 8m, 5f); Georgia: Liberty Co., St. Catherines Island (AMNH 17633, 9m, 1f); (AMNH 17745, 3m); (AMNH 17658, 5m, 2f); (AMNH 17744, $4 \mathrm{~m}) ;($ AMNH 17639, 3m); McQueen Inlet, $\mathrm{N}$ from South Beach (AMNH 17746, 3m); (AMNH 17747, 3m); Cracker Tom Hammock (AMNH 17748, 2m, 3f); Florida: Matanzas River, (USNM 99904, 9m, 6f); St Augustine, St Johns Co., Johnson's Fish Camp (AMNH 14784, 36m); Crescent beach (AMNH 14761, 47m, 5f); Flagler Co., Flagler Beach Bridge (AMNH 14751, 5m, 3f); (AMNH 14773, 4m, 8f); Volusia Co., New Smyrna Beach (AMNH 14764, 53m, 3f); Shilon and Cocoa (AMNH 8669 part, 4m, 2f); Ponce Park (USNM 39193, 1m); Indian River (USNM 170171, 5m, 1f, 3ovf); (USNM 170172, 7m, 3f); Boca Raton (AMNH 16210, 1m); Fort Lauderdale (USNM 138636, 2m, 2f); Miami (AMNH 3014, 5m, 2f); Coral Gables (USNM 76118, 1m); Coconut Grove (USNM 48924, 7m, 3f); Key West (USNM 18552, 2m); Cape Sable Creek, (USNM 15254, 13m, 18f); Marco (USNM 71254, 1m, 3f); (USNM 


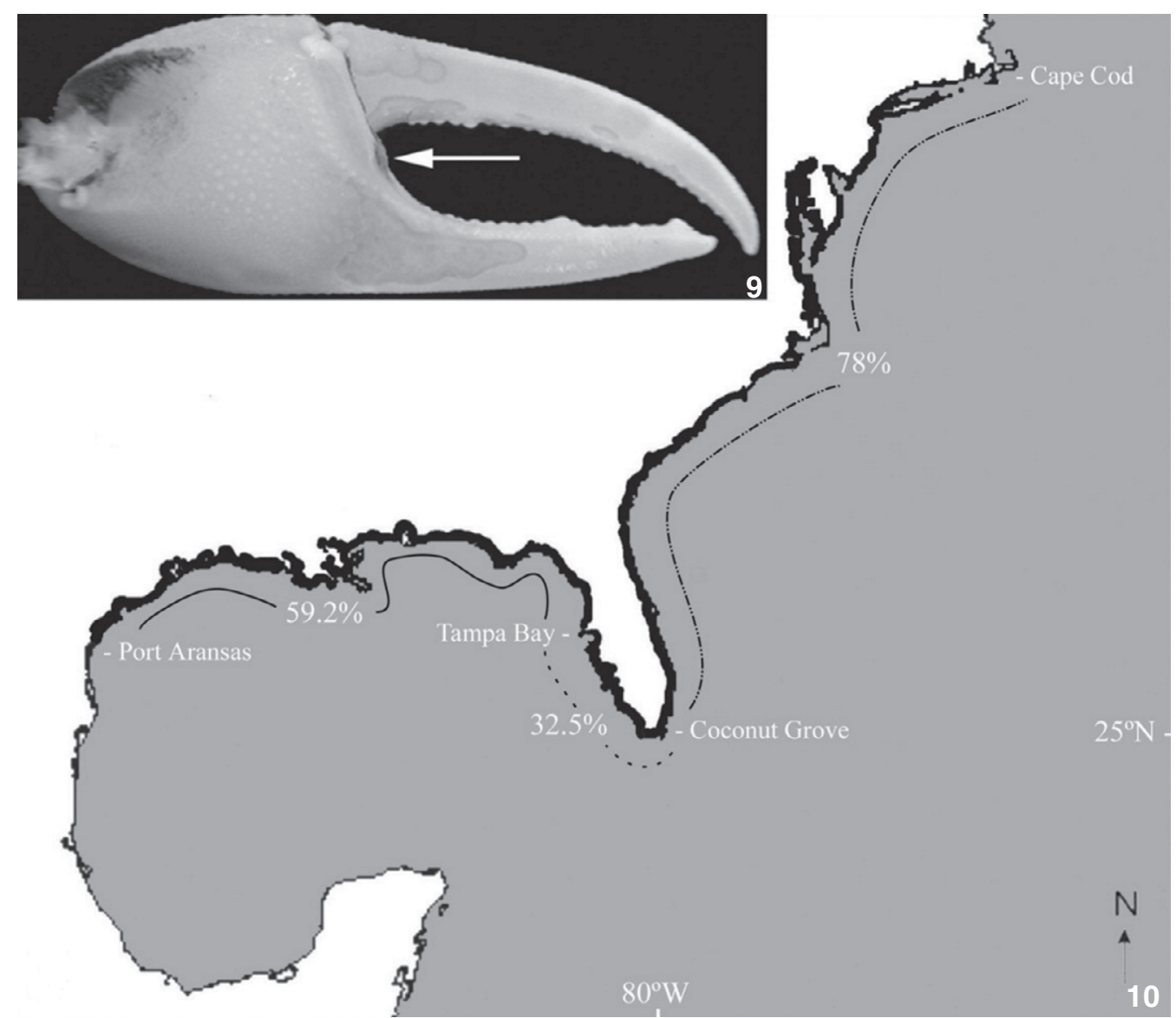

Figures 9-10. (9) Major chela of U. pugilator with gape pile (arrow). (10) Percentage of specimens of U. pugilator with gape pile along its area of occurrence.

6964, 21m, 8f); (USNM 15252, 2m, 1f); Punta Rasa (USNM 6435, 33m, 10f); Punta Gorda (AMNH 2600, 1m); (AMNH 2886, 2m, 2f); (AMNH 2631, 3m, 1f); Seven Oaks (AMNH 2389, 2m); Pine Key (USNM 6440, 40m, 7f); Tampa Bay, St. Petersburg (USNM 75579, 21m, 9f); Tampa Bay (USNM 55548, 1f); Clearwater (USNM 3276, 7m, 11f); Cedar Keys (USNM 6412, 25m, 25f); Spring Creek (USNM 65772, 2m, 2f); Franklin Co., St. Andrews Bay (AMNH 16331, 4m, 4f); Panacea (USNM 125578 part, 3m); Panama City, Bay Co. (AMNH 16374, 2m, 1f); (AMNH 16381, 1f); (AMNH 16336, 4m, 2f); Pensacola (USNM 180190, 1m, 1f); Alabama: Mobile Co., Bayou la Batre, Point Aux Pins (AMNH 9030 part, $1 \mathrm{~m})$; Louisiana: Breton Island (USNM 64084, 3m, 1f); Chandelleur (USNM 92430, 2m, 4f); Texas: Port Aransas (USNM 104738, 1m). Bahamas: Andros Island (AMNH 2406, 1m, 1f). West Indies, Dominican Republic: Santo Domingo (AMNH 2555, 4m, 1f).

\section{Morphological variations}

Regarding the differences between $U$. panacea and $U$. pugilator pointed out by BARNwell \& Thurman (1984), some examined specimens of $U$. panacea present small tubercles on dorsal margin of carapace as in U. pugilator (Figs 1 and 2), as well as the branchial chamber, which is depressed relative to the central gastric region. Moreover, Barnwell \& Thurman (1984) pointed out that a purple pigment spot may occur anterior to the $\mathrm{H}$-form depression on the carapace of $U$. pugilator and not in U. panacea. However, this character is only good for live or recently preserved specimens, given that it does not persist in $70 \%$ ethanol. This pigment spot is easily confounded with another pigment present on the dorsal margin of carapace called gnathobases attachment, which may occur in both species. In $45 \%$ of the $U$. pugilator specimens examined, gnathobases attachment is absent (Figs 3-6).

The tubercles on the anterior surface of merus on the major side of first ambulatory in $U$. pugilator are less numerous compared to those in $U$. panacea (Figs 7 and 8). These tubercles are a diagnostic character between the species, confirming the previous statement by BARNwELL \& THURMAN (1984).

Some $U$. pugilator specimens possess a gape pile in the major cheliped (Fig. 9). The major chela was absent in 53 of the 734 males examined; so, in 681 males with major chela examined, the pile was present in 442 specimens (65\%), and in 

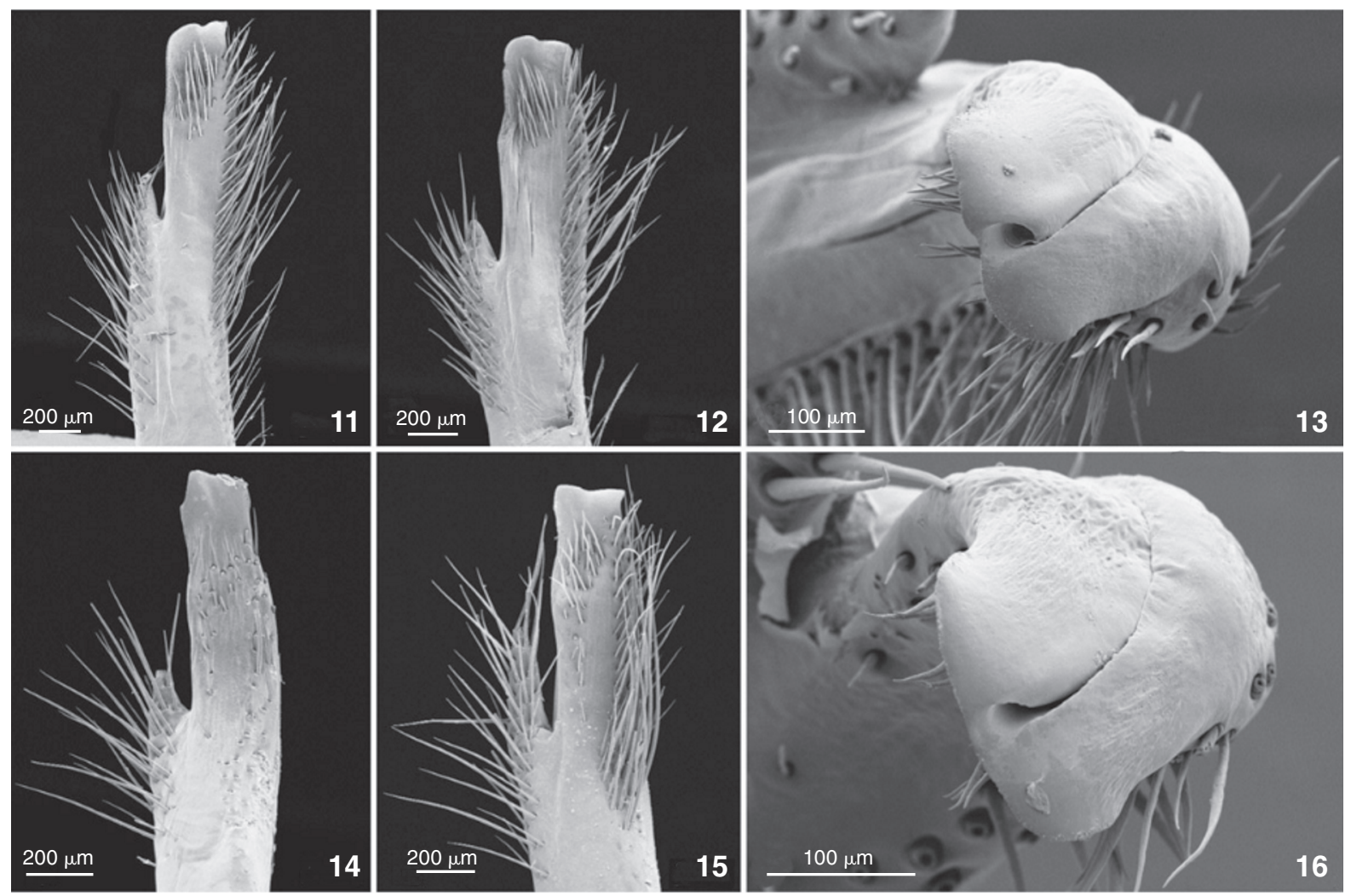

Figures 11-16. Scanning electron micrographs of the right gonopods of U. panacea (11-13) and U. pugilator (14-16). (11) USNM 150098, paratype, Panacea, Florida, carapace width 16.5 mm; (12-13) USNM 180188, Mexico, Laguna La Mancha, carapace width 18 mm; (14) USNM 55553, United States, Virginia, carapace width 16 mm; (15) USNM 6440, United States, Pine Key, Florida, carapace width 23 mm; (16) USNM 17186, United States, South Carolina, carapace width $15.5 \mathrm{~mm}$.

$239(35 \%)$ the pile was absent. Considering the areas of occurrence of both species (Fig. 10), along the US Atlantic coast, where $U$. panacea is absent, 358 out of 485 specimens examined had the pile $(78 \%)$. Of the $U$. pugilator examined from south of Tampa Bay, 39 out of 120 (32.5\%) had pile present. In the sympatric area (north of Tampa Bay) the pile was present in 45 out of 76 specimens examined (59.2\%).

The females of both species have the dorsal region of carapace granulated. Females of $U$. pugilator bear large tubercles on the antero-lateral region, as previously observed by BARNwELL $\&$ Thurman (1984). However, some of $U$. panacea females have tubercles on the dorsal region of carapace very similar to those of $U$. pugilator. Reliable distinction between single preserved females of these two species remains a difficult task.

\section{SEM analysis of the gonopod}

The SEM analysis has revealed that the distance from the base of the sub-terminal thumb to the tip of the gonopod in $U$. panacea is shorter than $U$. pugilator, as well as the thumb itself as observed by Barnwell \& Thurman (1984). The length of the sub-terminal thumb in $U$. panacea is approximately one third of the length from the tip of the gonopod to the sub-terminal thumb base, whereas in $U$. pugilator the length is about half. However, when small specimens are analyzed, this difference is negligible (Figs 11 and 14). Thus, this is a very slight difference, being most conspicuous in large specimens (Figs 12 and 15), as also observed by Barnwell \& THuRMAn (1984). We examined in detail the tip of the gonopod of both species and found no apparent differences (Figs 13 and 16). In contrast to the drawings provided by NOVAK \& SALMON (1974), our analysis has revealed no differences on the curvature of the appendage.

\section{DISCUSSION}

Among the Gulf of Mexico fiddler crab species, U. pugilator and $U$. panacea are a typical case of cryptic species; although live specimens are clearly distinguishable by differences in color and behavior, only slight morphological differences separate these two species (MAYr 1963, Dr M. SALMON 2007, pers. comm.). According to M. SALMON (pers. comm.) the species occupy different niches and are sufficiently different in their courtship behavior to avoid any interbreeding. Hybrids of the species are 
not known. When the two species were forced to interbreed in laboratory by isolating males of one species with females of the other, most of the larvae died and those that survived were apparently infertile (SALMON et al. 1978).

However, according to von Hagen (1980), "nobody can fully estimate the degree of intra-specific variation of e.g. sound production in $U c a$, it is necessary to centre on morphological characters, the variations of which are far better known in many cases." The failure to account for intraspecific variation, allied to the inability of taxonomists to reach agreement about the status of some forms and the limitations of working with small number of specimens, sometimes poorly preserved (BARNwELL $\&$ Thurman 1984), has been responsible for the description of non-valid species in recent years (e.g. U. virens Salmon \& Atsaides, 1968, U. pavo George \& Jones, 1982).

The discovery of new reliable diagnostic morphological characters in Uca species has helped to solve previously contested taxonomic status among some species, such as between Uca pugnax (Smith, 1870) and U. rapax (Smith, 1870) (TASHIAN \& Vernberg 1958); U. minax (LeConte, 1855) and U. longisignalis Salmon \& Atsaides, 1968 (Thurman 1982); U. virens and U. rapax (von Hagen 1976, 1980). Some species have been restored to specific rank, such as U. speciosa (Ives, 1891) and U. spinicarpa Rathbun, 1900 originally assigned by RATHBUN (1918).

In addition to the morphological differences pointed out by Barnwell \& Thurman (1984) between $U$. panacea and $U$. pugilator, the presence of gape pile was found in some $U$. pugilator specimens. However, it is important to keep in mind that presence/absence of gape pile is a variable character, and was only present in $65 \%$ of $U$. pugilator examined. Crane (1975) speculated that the gape pile serves as a kind of buffer during the combat, masking noise or tactile sensations that might interfere with stimuli resulting from the rubbing of the gape tubercles along the predactyl ridges of the opponent. This kind of combat, named pregape-rub, was clearly observed three times, only in $U$. pugilator (Crane 1975). The absence of gape pile in some specimens may be because the pile is fragile and easily dislodged, thus its occurrence is not specially mentioned in the systematic descriptions (Crane 1975). Therefore, the pile could not be considered a reliable diagnostic character. On the other hand, this variable character may be useful in species identification.

The increase in the use of new morphological characters has been important to taxonomists in distinguishing very similar species, mainly regarding the $U c a$ species from Gulf of Mexico, where many closely related species are found (BARNwELL \& Thurman 1984, Rosenberg 2001, Beilinch \& von Hagen 2006).

The differences in gonopod morphology are useful only when large specimens are compared. Moreover, it is necessary to examine large series of specimens of several sizes to proceed to a confident distinction between these fiddlers based on gonopod morphology. vON HAGEN (1980) was unable to distinguish between the gonopods of the holotype of $U$. panacea and
$U$. pugilator, probably because he examined specimens of $U$. pugilator of similar size of the holotype of $U$. panacea (approximately $16 \mathrm{~mm}$ of carapace width). At this size the differences in gonopod morphology are negligible.

In conclusion, the intraspecific variations found by us in preserved specimens of $U$. pugilator and $U$. panacea, as well as the additional morphological character in $U$. pugilator, allied to the SEM images of gonopods of both species, could help in identification of preserved specimens and avoidance of confusion between these two species.

\section{ACKNOWLEDGEMENTS}

We especially thank Rafael Lemaitre and Mark Siddall for the facilities given to the first author for the revision of $U c a$ species deposited in the collection at the Smithsonian Institution, Washington DC and American Museum of Natural History, New York, respectively; Scott Whittaker (USNM Image Laboratory) for the invaluable help with the SEM analysis at the NMN History's SEM laboratory and Alexandre Almeida (DCB/UESC), for his usual support. L.E.A. Bezerra thanks PROPESQ/UFPE for the provision of a PhD scholarship and CAPES for the provision of a travel grant to visit collections abroad. P.A. Coelho thanks CNPQ for a provision of research productivity scholarship. Special thanks to T. Chad Walter, USNM, for the suggestions, criticisms and revision of written English language and C. Thurman (University of Northern Iowa), for criticisms and suggestions.

\section{LITERATURE CITED}

BARNwell, F.H. \& C.L. Thurman. 1984. Taxonomy and biogeography of the fiddler crabs (Ocypodidae: Genus Uca) of the Atlantic and Gulf coasts of eastern North America. Zoological Journal of the Linnean Society 81: 23-87.

Beilinch, B. \& H.O. von Hagen. 2006. Material for a more stable subdivision of the genus $U c a$ Leach. Zoologishe Mededelingen 80: 9-32.

Bosc, L.A.G. 1802. Histoire naturelle des crustacés, contenant leur description et leur moeurs; avec figures dessinées d'aprés nature. Paris, Deterville, vol. 1.

Crane, J. 1975. Fiddler crabs of the world (Ocypodidae, Genus Uca). Princeton University Press, XXIII+736p.

Felder, D.L.; K.R. Rao \& M. Fingerman. 1971. A female-limited lipoprotein and diversity of hemocyanin components in the dimorphic variants of the fiddler crabs, Uca pugilator, as revealed by disc electrophoresis. Comparative Biochemistry Physiology B 39: 291-297.

Felgenhauer, B.E. 1987. Techniques for preparing crustaceans for scanning electron microscopy. Journal of Crustacean Biology 7 (1): 71-76.

Fingerman, M. 1956. Phase difference in the tidal rhythms of color change of two fiddler crabs. Biological Bulletin 110: 274-290. 
Fingerman, M. 1957. Relation between position of burrows and tidal rhythm of Uca. Biological Bulletin 112: 7-20.

George, R.W. \& D.S. Jones. 1982. A revision of the fiddler crabs of Australia (Ocypodinae: Uca). Record of the Western Australian Museum 14 (Suppl.): 1-99.

Hyman, O.W. 1920. The development of Gelasimus after hatching. Journal of Morphology 33: 485-501.

Ives, J.E. 1891. Crustacea from the northern coast of Yucatan, the harbor of Vera Cruz, the west coast of Florida and the Bermuda Islands. Proceedings of the Academy of Natural Sciences of Philadelphia 43: 176-207.

KIngSLEY, J.S. 1880. Carcinological notes, No. II. - Revision of the Gelasimi. Proceedings of the Academy of Natural Sciences of Philadelphia 20: 135-155.

LeConte, J. 1855. On a new species of Gelasimus. Proceedings of the Academy of Natural Sciences of Philadelphia 7: 402403.

MaYr, E. 1963. Animal species and evolution. Cambridge, Harvard University Press, 797p.

NovaK, A. \& M. Salmon. 1974. Uca panacea, a new species of fiddler crabs from the Gulf coast of the United States. Proceedings of the Biological Society of Washington 87 (28): 313-326.

Ortmann, A. 1897. Carcinologishe Studien. Abtheilung für Systematik, Geographie und Biologie der Thiere 7: 683772.

PAWLIK, J.; R. LEWIS \& F.H. BARNWELl. 1980. Different mechanism of sound production in two closely related species of fiddler crabs. American Zoologist 20: 957.

Powers, L.W. 1977. A catalogue and bibliography to the crabs (Brachyura) of the Gulf of Mexico. Contributions in Marine Science 20 (Suppl.): 1-190.

RaO, K.R. \& M. Fingerman. 1968. Dimorphic variants of the fiddler crab Uca pugilator and their chromatophore responses. Proceedings of the Louisiana Academy of Sciences 31: 27-39.

Rathbun, M.J. 1900. Synopses of North-American invertebrates, XI. The catometopus or grapsoid crabs of North America. American Naturalist 34: 583-592.

Rathbun, M.J. 1918. The grapsoid crabs of America. Bulletin of the United States National Museum 97: 1-461.

Rosenberg, M.S. 2001. The systematic and taxonomy of fiddler crabs: A phylogeny of the Genus Uca. Journal of Crustacean Biology 21 (3): 839-869.

SAlmon, M. \& J.F. Stout. 1962. Sexual discrimination and sound production in Uca pugilator Bosc. Zoologica 47 (3): 15-20.

SAlmon, M. \& S.P Atsaides. 1968. Behavioral, morphological and ecological evidence for two new species of fiddler crabs (Genus $U c a$ ) from the Gulf coast of the United States. Proceedings of the Biological Society of Washington 81: 275-289.

Salmon, M. \& G.W. Hyat. 1979. The development of acoustic display in fiddler crab Uca pugilator, and its hybrids with Uca panacea. Marine Behaviour and Physiology 6: 197-209.

Salmon, M.; G. Hyatt; K. McCarthy \& J.D. Costlow Jr. 1978. Display specificity and reproductive isolation in the fiddler crabs, Uca panacea and U. pugilator. Zeitschrift für Tierpsychologie 48: 251-276.

Selander, R.K.; W.E. Johnson \& J.C. Avise. 1971. Biochemical population genetics of fiddler crabs $(U c a)$. Biological Bulletin 141: 402.

SмITH, S.I. 1870. Ocypodoidea. Notes on American Crustacea. No. I. Transactions of the Connecticut Academy of Arts and Science 2: 113-176.

Stimpson, W. 1859. Notes on North American Crustacea. No. I. Annals of the Lyceum of Natural History of New York 7: 49-93.

Tashian, R.E. \& F.J. Vernberg. 1958. The specific distinctness of the fiddler crabs Uca pugnax (Smith) and Uca rapax (Smith) at heir zone of overlap in northeastern Florida. Zoologica 43: 89-92.

Thurman, C.L. 1982. On the distinctness of the fiddler crabs Uca minax (LeConte) and Uca longisignalis Salmon and Atsaides in their region of sympatry. Crustaceana 43: 37-50.

Von Hagen, H.O. 1976. Review: Jocelyn Crane, Fiddler Crabs of the World. Crustaceana 31: 221-224.

Von Hagen, H.O. 1980. A key to "x-species" of North American fiddler crabs (Genus Uca). Zoologishe Mededelingen 55: 87-96.

Submitted: 11.VIII.2008; Accepted: 13.III.2009.

Editorial responsibility: Marcos Tavares 